\title{
Pennsylvania's Roads
}

\section{The Comprehensive Highway Engineering Plans of the Keystone State}

\author{
By William McGarry
}

$A^{N}$ engineering feat far greater in total outlay of A funds than the Panama Canal is going on quietly in Pennsylvania. Hardly anything is heard of it except when some unlucky motorist gets mired down in a detour over one of the execrable roads that the Keystone State is rushing to replace with what will be the finest highway system in the world.

To date Pennsylvania has built and has in service more than 500 miles of reinforced concrete road built to carry loads of 13,000 pounds, more than 100 miles of road made up of a concrete base with bituminous top, or plain concrete; more than fifty miles of brick road, and an equal stretch of sheet asphalt and new macadam highway.

The proportions here offer a fairly good indication of what the state is attempting to do, for the same ratio of reinforced concrete will govern in the construction of a primary system of highways to cover erentually more than 4,000 miles. At the present writing about 750 miles of this work is under contract and the state, work is une state, for permanent, high-speed road building, is out to set a new figure which may stand for years.

With conditions of labor and material markets vastly improved over those existing last year, it is a foregone conclusion that the record made in 1920 will be that the rocosite shortage excectertage in cost that forced the abandonment of many similar projects, Pennsylvania

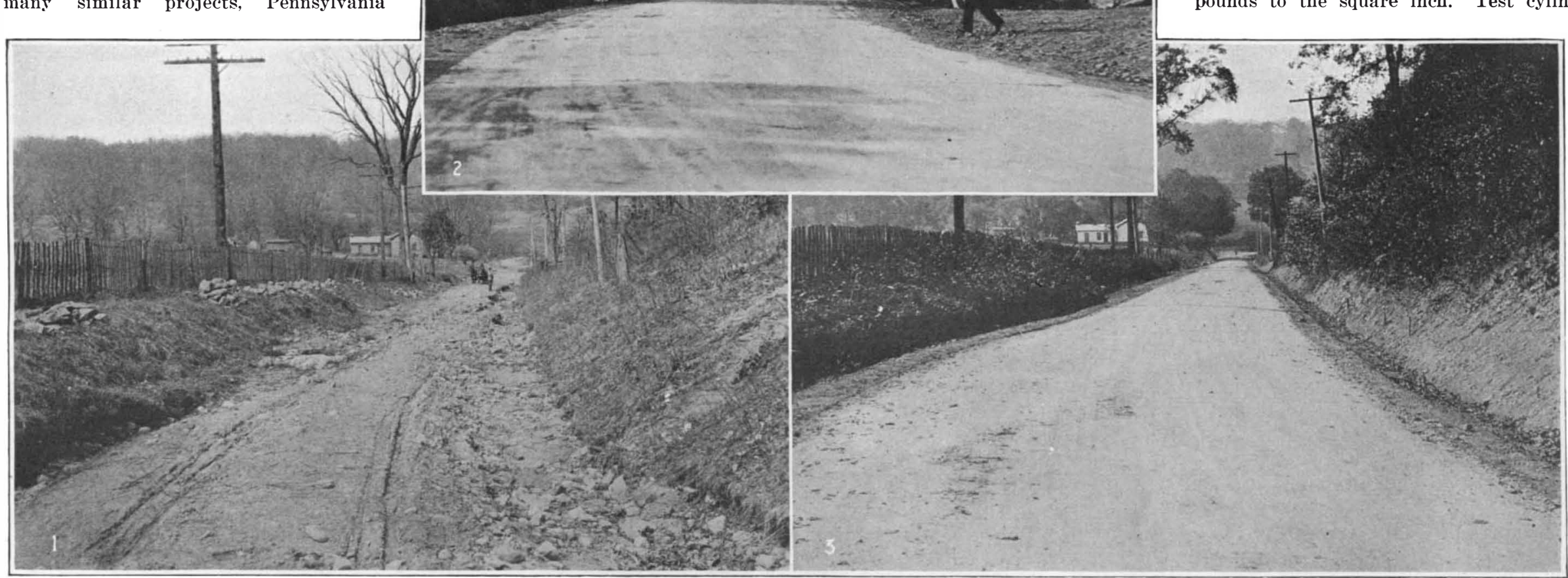

1. A strip of typical Pennsylvania road before the automobile era. 2. A bit of the Lincoln Highway in Fulton County, Pa. 3. The same stretch of roadway shown in the first view, as it is today Pennsylvania's roads before and after taking the treatment prescribed by the State's highway engineers

forged ahead and completed a total of 413.87 miles of durable thoroughfare.

Work had been started at the close of the season last year on an additional 450 miles of highway, which the Department was unable to finish because of the coming of winter. It is planned to add to this contracts for a total of 400 miles this summer-in fact, 300 miles already has been let and work has been started. Before the end of the summer many through routes will have been completed and open for service.

The entire cost of the "primary system"-laid out so that it will be possible for a citizen in any part of the states to reach any other section over it-is being borne by the state. For this and other road work in its program the Highway Department has available more than $\$ 125,000,000$, including bond issues and appropriations, and Federal funds. The bond issue is $\$ 50,000,000$

Perhaps the most remarkable feature of the Pennsylvania plan is that every mile on the new primary system of highways was put there only after a thorough survey. This was made over existing routes to determine their availability, locally and to the state at large. In every instance, when it was found that a at the expense of the entire state, changes were made in the routing.

In some instances miles of old road were abandoned, so far as the new state highway plan is concerned, so that new concrete highways might be laid on lines as nearly straight as possible. There is hardly a road in the system crossing a hill of any consequence in which the grade has not been changed, sometimes at heavy cost. The whole thing is worked out by engineers equipped with a knowledge of the pulling power of motor trucks and other traffic for which these roads are being built. Pennsylvania is trying to build a highway system on which no vehicle will ever get stuck save as the result of a mechanical defect. Grades are made passable.

The importance of this will be instantly apparent and a quarter miles by the elimination of unnecessary

One of the best things about the new system is that it is eliminating many of the most dangerous grade crossings. There were two of these on the Lincoln Highway near Langhorne, $\mathrm{Pa}$. Both have been eliminated in the new survey. The old road looped at this point and made two crossings. By straightening out the loop it was possible to do away with both crossings by a single undercut of the railroad track.

Highway engineers throughout the country have been watching some of the roadbuilding in the Keystone State with unusual interest. For instance, the greater part of the new concrete road from Philadelphia to West Chester, a distance of twenty-one miles, which is nearing completion at this writing, is laid on the old macadam road. This old road was in a bad state of repair. It was leveled off to form the foundation for the concrete. The result is a roadbed of rock and concrete as deep in the arorecate as that of the famous in the aggregate as that of the famous opinion of engineers should last for many years.

Pennsylvania's primary highways for heavy traffic are constructed of an eightinch depth of concrete in the center, tapering to six inches on the sides. Two inches from the top is laid a fifty-sixpound wire mesh reinforcement The specifications require that the road shall withstand a pressure of two thousand pounds to the square inch. Test cylin- o motor truck experts who have tried to send heavy e assumed, however, that because the Department is taking advantage of every possible short cut and makes deep cuts through hills that it has ignored the value to the state of preserving the scenic features of its roads. The new system will open to modern motor travel some of the loveliest spots in the state, heretofore closed to those who refuse to take chances on wrecking their cars. It will open also the hunting territories in the western section and hill regions where few cars ventured in previous years.

The primary system does not include many hundreds of miles of road, some of it of the heavy reinforced concrete type, being built in cooperation with county authorities and the Federal government. In general, the state's system includes through highways, and roads connecting the various county seats. Particula attention has been paid in the surveys of through routes used for long distance hauls to the matter of short cuts. An idea of what has been done here is evident from the fact that the Lincoln Highway from Trenton to Philadelphia has been reduced about two ders are taken by inspectors employed by the State Highway Department every 1500 feet and sent to Harrisburg for examination. Expansion joints are laid on straight runs at the end of each day's run, and at all points of grade or curve where they may be considered necessary.

Last year the concrete was fed into the big mixing machines by gangs of shovelers. Examination of test cylinders, and of sections broken from cracks appearing in the finished road, convinced the State Engineers that most of the failures of the construction were due to the mixture of dirt and occasionally debris in the concrete, as when a gang cleaned up the roadbed preparatory to moving the machine. Accordingly, the specifications this year provide that there shall be no dumping of anything on the subgrade. Cement in bags, heretofore stacked on the grade, is now carried alongside the right of way. Most of the contractors at work on the state highways now use one-ton trucks for the concrete materials. These are loaded in two sections with just the right proportions of stone and sand. These essential materials are dumped directly (Continued on page 155) 


\section{LEGAL NOTICES}

\section{PATE N T S}

IF YOU HAVE AN INVENTION Which you wish to patent you can Cesfor advice in regard to the best Ces or advice in regard to the best
way of obtaining protection. Please way of obtaining protection. Please
send sketches or a model of your insend sketches or a model of your in-
vention and a description of the vention and a description
device, explaining its operation.

All communications are strictly confidential. Our vast practice, extending over a period of seventy years,
enables us in many cases to advise enables us in many cases to advise
in regard to patentability without in regard to patentability without
any expense to the client. O Our Handany expense to the client. Our Hand-
Book on Patents is sent free on reBook on Tatents is sent free on re-
quest. This explains our methods, terms, etc., in regard to Patents,
Trade Marks, Foreign Patents, etc. SCIENTIFIC AMERICAN Contains Patent Office Notes, Decisions of
interest to ineventors -
cend particalars of re-

\section{MUNN \& CO., SOLIDTPIRS Woolworth Bailding.
Tower Bailding.
CHEW YORK Tower Bnilding,
Scientific American Buildings, WASHINGTON, D.C.
Hobart Baidding,}

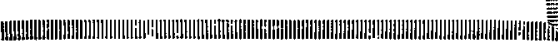

Annual Subscription Rates Scientific American Publications Sciontific American (established 1845) one
year $\ldots \ldots \ldots \ldots \ldots \ldots$ Scientific
1876) one year Monthly (estabilished $\$ 7.00$ Postage prepaid in United states and posses
sions, Mexico, Cuba and Panama. Foreign Postage
Scientific American \$1.50 per year additional
Scientific American Monthly $72 \mathrm{c}$ per year ad
ditional Canadian Postage

Scientifc American 75c per year additional.
Scientific American Mon,thly $36 \mathrm{3c}$ per year addThe combined subscription rates and rates to Remit by postal or express money order, ban
funtication.

Classified Advertisements

Advertising in this column $18 \$ 1.00$ a line.
No less than five nor more than 12 lines
accepted. Count seven, words to the line. All accepted. Count seven, words to the line. All
orders must be accompanied by a remittance. BUSINESS OPPORTUNITY

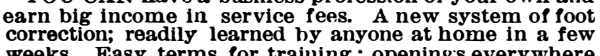

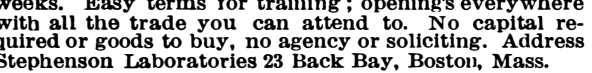
BUSINESS OPPORTUNITY

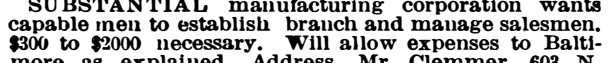
more as explained. Addra
Euttaw St., Baltimore. Md.

FOREIGN STAMPS

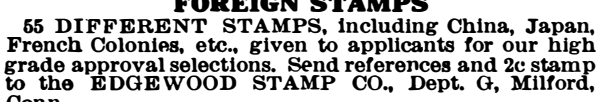

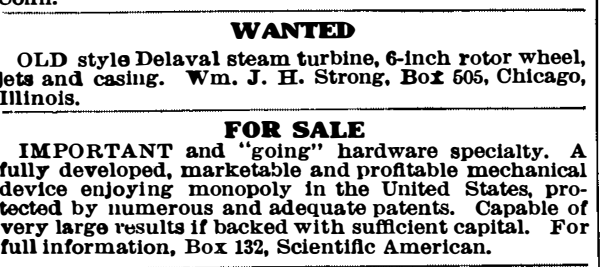

INVENTIONS DEVELOPED

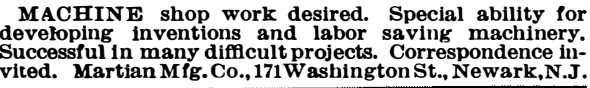
WANTED

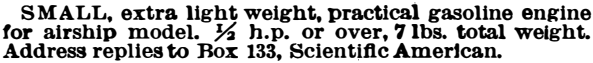
ADVERTISEMENT

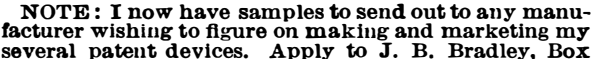
several patent
1230, Miami, Fla.

\section{We Will Make It}

Anything in a metal stamping or novelty pro-
duced from any metal and f f nished in any color.
Waterbury Button Co., Waterbury, Conn.

Valuable Books of Instruction and Reference

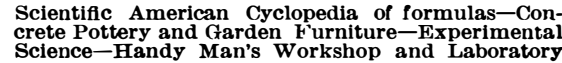

Send for Booklet
SCIEMTIFIC AMERICAN PUBLISHING CO., Woolworth Bldg, New Yort
Pennsylvania's Roads (Continued from page 144) into the buckets of the concrete mixers. Another result of this in addition to the marked improvement of the finished road and the reduction in cracks is that it speeds up construction. Records from which might be struck an average of day runs are not yet available, but under the present system engineers say there has been a decided increase in this average. On one typical job-that on the West Chester Pike previously referred to-a gang of forty men has been averaging 365 feet of new road every day of twelve hours. The minimum day run has been about 300 feet, the maximum 506. Five trucks operate with this gang. One section of two and a quarter miles for which the contract allowed one hundred

With the dumping of materials direct from trucks to the mixing machine a second handling is eliminated. The curing process in Pennsylvania follows the general modern highway engineering practice in other states. Roads are leveled with a template and the morning with gravel and the day's run is covered daily for eight days to permit the concrete to dry uniformly. The covering is left on for twenty-one days, by which time the road is ready for use.

Engineers at work on the system say that cracks in the concrete are runnin from three to six a half mile, but in nearly every case, under the new specifislight ind effect this year, the fissures are surfacing above the wire reinforcement These are filled at once with the asphalt mixture used in making the expansion joints and so far cracks so treated have not shown any appreciable widening. Last year the concrete road cost in Pennsyl vania went up to $\$ 60,000$ a mile, an in crease of nearly $\$ 25,000$ over pre-war figures. The total cost for the mileage under construction this year is not expected to exceed $\$ 50,000$ and

On grades of eight per cent and lesser grades running on sharp curves the Department is laying a paving of hillside brick, cut to afford a grip to the caulks of crete, on a base of six inches of conwith a wire cut lug, and is grouted in with cement. On this type of road the mixture for the concrete base is one part cement, three parts sand and six part stone. For the plain and reinforced concrete roads the mixture is one par stone

\section{A Problem and Its Attempted Solution}

(Continued from page 146)

the new design. It contains copies placed in the compartments about four months before the photograph was taken it was in no way "dressed up" for the
purpose of taking the view. A comparison between this picture and Fig. 1 is complete demonstration of the difference between the customary and the newly worked out means of storing copies. The patents in both cases show the results of four months' pulling from groups whic at the beginning of the period were in perfect alinement and proper sequence.
The case illustrated in Figs. 2 and 3 , while demonstrated practicable and vastly superior to the old way beyond any possibility of doubt, is a long way from be ing standardized as the regular Patent Office procedure. This case is not of cheap construction; on its face it cost considerably more than open bins of this style of equipment cannot proceed without special provision for it in the regular appropriation or in a special bill The Patent Office, since the demonstration of the advantages of the new-style case, has managed to provide enough funds to install eight of the units shown in Fig. 2. These eight units will hold eight weekly issues of patents. Perhaps the implication that the Patent Office very week issues enough patents to inure that a stock of the copies will fill a case of these proportions will be illuminating to some who had not realized the scale upon which Patent Office operations re carried out.

The ideal, of course, would be the proision of sufficient money to enable the Patent Office to store its entire stock of copies, within a reasonable time, in filing cases of this character. This ideal fficacy of will be approached when the onstrated beyond question. With the appropriations that are available for the resent fiscal year beginning July 1, 1921, an installation for almost a year's use may be instituted. Whether appropriations can be obtained for the $1,400,000$ bundles of patents already granted to sufficient and expensive conditions in which they are now stored is a matter for hope and future determination.

The point, however, is obvious. Copies and copy-pulling has always been the skeleton in the Patent-Office closet, for the very excellent reason that no method which would make the storage and the pulling clean and precise. Now such a method is known, and at the disposal of the Patent Office. It has been demontrated on a scale small enough to be sure, yet large enough to give foundation for the estimate that if the entire installation of patent files were of this atest type, a reduction of force of 30
per cent in the copy-pulling branch of the Patent Office could be made with a reduction of inaccuracy of 90 per cent. It is difficult to exaggerate the loss to comcertain patent is "out" when it is merel certain patent is "out" when it is merely out of place, and the loss to the Govern-
ment through the reprinting of patents that are thus erroneously reported to be exhausted. Along with these gains, there would automatically come a material reduction in the extent of executive superan appreciable increase in revenue from an appreciable increase in revenue from ime sale of copies, and an immeasurable speed of the service to the public. Finally, if the framing were of steel instead of wood there would be attained a favorable condition not now existing in the miles of inflammable shelving spread through the corridors and galleries of the Patent Office. But of course the immediate problem is to obtain equipment that will permit service ; collateral advantages' are of merely collateral importance. The way has been shown how to dispose of this vexing Patent Office problem for all time; made to see the wisdom of making it possible for the Patent Office to put into effect the solution thus offered.

The Largest Crater in the World T Wo Swedish scientists named Waddel 1 and Ygberg recently made a journey of exploration through Iceland with the interesting result that they discovered the largest volcanic crater in the world. It took them nine days, using three horses and sledges to cross the great sea of ice order to reach Kolar on the Fjord of Hornar. Upon the Högjökel they found a tremendous volcanic crater containing hot water and no less than 8 kilometers rounded by a number of hot springs. The Swedish savants who discovered it named it the Svea crater, and it is regarded as not only the greatest crater in Iceland
but probably, so far as is known at present, the largest in the world.

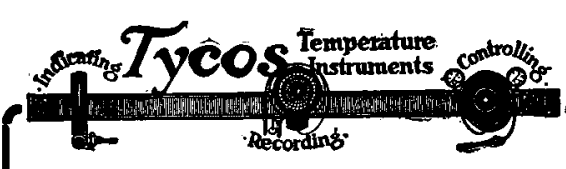

The name indicates what Tycos means-a complete service. Industry brings its temperature problems to the Tycos organization because its products embrace every need, every especial requirement that manufacturing conditions may call for.

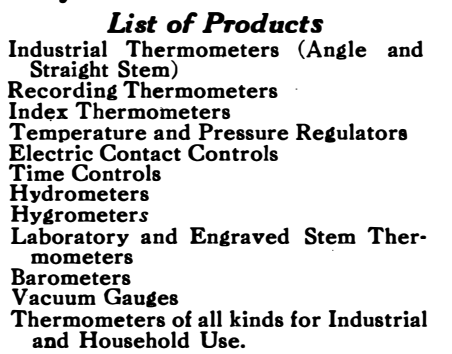

Taylor Instrument Companies Rochester, N. Y.

There's a Troos or Igtar Temperature Instrument
for Every Purpose

For Gunsmiths, Tool Makers, Experimental \& Repair Work, etc.

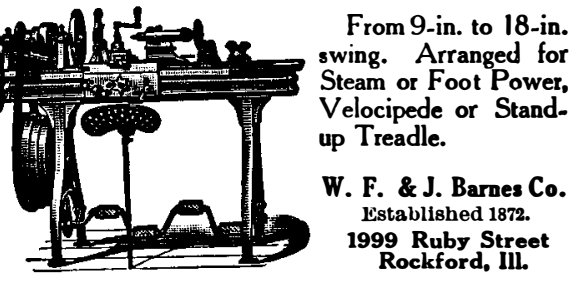

GAS. AIR, WATER, GASOLINE PUMPING LEIMAN BROS. AIR PUMPS

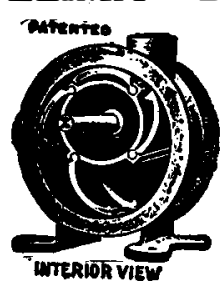
ROTARY-POSITIVE
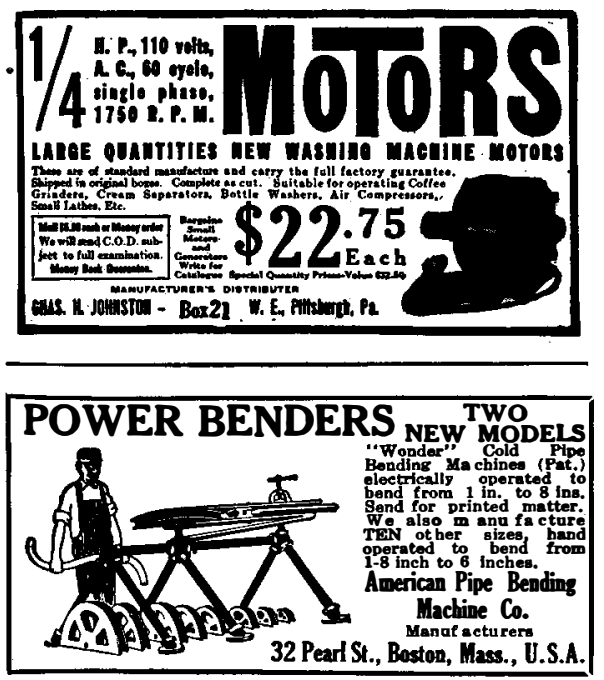

MAXIM SILENCERS

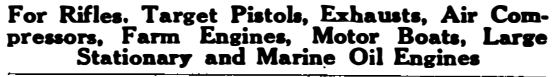
Manufacturing rights available. Write for information

MAXIM SILENCER COMPANY
94 Homestead Ave.

THESCHWERDTLE STAMP CO

STEEL STAMPS LETTERS \& FIGURES BRIDGEPORT CONN. 